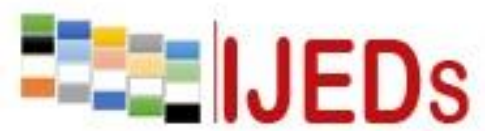

http://ijeds.ppj.unp.ac.id/index.php/IJEDS

\title{
THE EFFECT OF NUMBERED HEAD TOGETHER (NHT ) COOPERATIVE LEARNING MODEL AND LEARNING MOTIVATION ON SOCIAL STUDIES LEARNING OUTCOMES FOR GRADE VII STUDENTS OF SMP 40 PADANG
}

\author{
* Fira Zarti ${ }^{1}$, Khairani $^{2}$ \\ ${ }^{1}$ Graduate Program of Social Science, Universitas Negeri Padang, Indonesia \\ ${ }^{2}$ Lecture of Faculty Social Science, Universitas Negeri Padang, Indonesia \\ Email: Firazarti1995@gmail.com \\ *Corresponding Author, Received: November 12, 201819, Revised: December 10, 2019, Accepted: December 21, \\ 2019
}

\begin{abstract}
This study aims to implement the Numbered Head Togerher (NHT) type of cooperative learning model in social studies subjects for grade VII students of SMPN 40 Padang. This research is an experimental research. Research instruments in the form of tests and questionnaires. Data analysis techniques using ANOVA. The results showed (1) student learning outcomes applied to the NHT type cooperative model were higher than student learning outcomes with conventional methods at SMPN 40 Padang. (2) The learning outcomes of students who have high motivation to learn are higher using NHT type cooperative learning models than students who have low motivation with conventional methods. (3) The learning outcomes of students who have lower learning motivation are higher using conventional learning models higher than using NHT learning models. (4) there is an interaction between the use of the Numbered Head Together (NHT) type of cooperative learning model and motivation in influencing student learning outcomes in social studies subjects in class VII SMPN 40 Padang.
\end{abstract}

Keywords : NHT Type Cooperative Learning Model, learning motivation, and learning outcomes

\section{INTRODUCTION}

Education has become the initial foundation of man through life, Education is held in principle in a democratic, open, civilized, and empowering way, building progress, developing creativity, building a culture of reading, writing, counting all components of education (Depdiknas, 2003). Humans in meeting their educational 


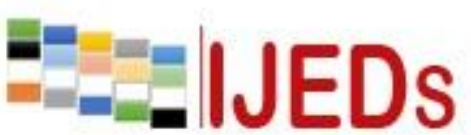

http://ijeds.ppj.unp.ac.id/index.php/IJEDS
International Journal of Educational Dynamics

Vol. 2 No. 1 (pp. 55-61) Desember 2019

p_ISSN 2655-4852

e_ISSN 2655-5093

needs can be through formal, non-formal, and informal channels. In connection with meeting the formal needs can be pursued through learning activities at school.

According to Law No. 20 of 2003 formal education is defined as a structured and tiered education pathway consisting of basic education, secondary education and higher education. One of the subjects provided in formal education is Social Sciences (IPS) which is given starting from elementary / MI / SDLB to high school / MA. For elementary / MI level, organizing subject matter uses an integrated approach (integreted), meaning that the subject matter is developed and compiled not referring to aspects of real life (factual / real) learners according to the characteristics of age, the level of thought development, and behavior and behavior habits. In the Permendiknas document it is found that the IPS examines a series of events, facts, concepts, and generalizations related to social issues. At the level of social studies in elementary / MI and junior high schools including Geography, History, Sociology, and Economics. Through social subjects students are directed to become citizens of Indonesia who are democratic, responsible, and citizens of a peaceful world.

From preliminary observations made by researchers on April 10, 2019 at SMPN 40 Padang, researchers found social studies teachers in providing material using only lecture and question and answer methods without using the learning models recommended in the 2013 curriculum. The learning process carried out using the method lectures cause students to become bored and not listen to the learning material delivered by the teacher, so that it is identified that students' motivation in the learning process is still low. Based on interviews with teachers in the field of social studies explained that the new curriculum K13 is used in class VII, while teachers are still accustomed to using conventional learning models. Social studies subjects contain a lot of learning material that requires students to be able to understand it, the tendency of teachers to explain the material using conventional learning models in social studies subjects in the form of lectures and questions and answers causes students to be less interested and passive so learning feels boring.

The low student learning outcomes in social studies are due to the fact that teachers are more likely to use conventional learning models, so students are less enthusiastic during the learning process. The conventional learning process carried out 


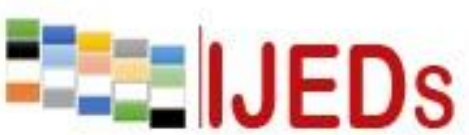

http://ijeds.ppj.unp.ac.id/index.php/IJEDS
International Journal of Educational Dynamics

Vol. 2 No. 1 (pp. 55-61) Desember 2019

p_ISSN 2655-4852

e_ISSN 2655-5093

by the field of study teacher causes students not to be involved in the learning process, students only receive more presentation of the material provided by the teacher, even students are less trained to develop ideas in solving a problem, the intensity of student learning is still too low, as well as limited (minimal) student involvement, this causes students not to be motivated in the learning process.

The application of various learning methods is needed as a solution to overcome these problems, one alternative problem solving is done by applying the learning method through the cooperative learning model of numbered head together (NHT) which requires students to be active, creative, and practice their abilities. to work together, be independent, and improve their ability to think highly. Isjoni (2010: 13) argues that some experts claim that cooperative learning models are not only superior in helping students understand difficult concepts, but are also very useful for developing critical thinking skills, working together, and helping friends.

The learning model koopera tif NHT is one type of cooperative learning that emphasize the specific structures that are designed to improve students' interaction patterns and has the goal of improving academic mastery. This type was developed by Kagen in Ibrahim (2000) by supporting students in examining the material covered in the lesson and examining their understanding of the content of the lesson. In addition, the cooperative learning model type Numbered head together (NHT) also provides opportunities for students to develop their Thinking Ability, and communicate the ability of students to both individuals and groups to develop that can improve student learning outcomes in terms of affective, cognitive abilities and psychomotor to achieve learning goals.

The influence of the application of the Numbered Head Together (NHT) model on student learning outcomes in the learning process is also supported by the results of research conducted by Juniati Harahap of the North Sumatra State Islamic University with the title 'The Effect of the Numbereded Heads Together (NHT) Method and Audiovisual Media on Educational Learning Outcomes Islam in Medan 12 Siswasma Negeri ". The results showed that (1) There was a positive influence on the learning outcomes of PAI students who learned by the Numbered Heads Together (NHT) method with an average value of student learning outcomes17,7. (2) There is a positive 


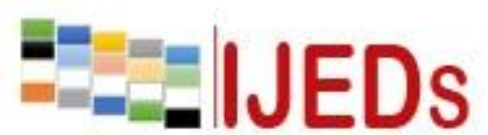

http://ijeds.ppj.unp.ac.id/index.php/IJEDS
International Journal of Educational Dynamics

Vol. 2 No. 1 (pp. 55-61) Desember 2019

p_ISSN 2655-4852

e_ISSN 2655-5093

influence on PAI learning outcomes of students who study with Audiovisual media with an average value of PAI learning outcomes of students 16.5. (3) There is a positive influence on the learning outcomes of PAI students who learn by using the Numbered Heads Together (NHT) method and Audiovisual media simultaneously with an average student learning outcomes of 23.6.

\section{METHOD}

This research was conducted using the experimental method. According to Sugiyono (2009: 107 ) "Experimental research methods are research methods used to look for the effect of certain treatments on others under controlled conditions". Meanwhile, according to Albone (2009: 60) experiment is a real situation by manipulating one or more independent variables in conditions that are carefully controlled by the experiment maker. This type of research conducted is quasiexperimental. The use of quasi-experimental research is to determine the effect of using the Numbered Head Together (NHT) learning model and learning motivation on student learning outcomes in IPS VII subjects at SMPN 40 Padang. $2 \times 2$ factorial design was used as a design in this study. (Dantes, 2012: 100) $2 \times 2$ factorial is the basic factorial design called by Kalinger. In a $2 \times 2$ factorial design, treatments are arranged so that each individual can be a subject simultaneously in two different factors, each of which consists of several levels. The independent variable in this study is the cooperative learning model type Numbered Head Together (NHT) with indicators of learning outcomes. While the intermediate variable is the level of learning motivation. Social studies learning outcomes are dependent variables with objective indicators of social studies learning outcomes. The instruments used were two, namely the student learning outcomes test and the learning motivation questionnaire.

\section{RESULTS AND DISCUSSION}

From the results of the study for the level of confidence $\alpha=0.05$ shows that the calculated L value for all groups is smaller than table L. Thus it can be concluded that the social studies learning data of all data groups A1, A2, B1, B2, A1B1, A1B 2 , $\mathrm{A} 2 \mathrm{~B} 1$, and $\mathrm{A} 2 \mathrm{~B} 2$ come from the normal distribution population. For more details about the overall test results can be seen in the table below. 
Table 1. Recapitulation of Data Normality Test Results

\begin{tabular}{|c|c|c|c|c|}
\hline Group & $\mathbf{N}$ & $\mathbf{F}_{\text {ut }}$ & $\mathbf{F}_{\text {tab }}$ & Conclusion \\
$\mathrm{A}_{1}$ & 30 & .101 & .16 & Normal \\
$\mathrm{A}_{2}$ & 30 & 0.078 & .16 & Normal \\
$\mathrm{B}_{1}$ & 30 & 0.110 & .16 & Normal \\
$\mathrm{B}_{2}$ & 30 & 0.09 & .16 & Normal \\
$\mathrm{A}_{1} \mathrm{~B}_{1}$ & 15 & .159 & .22 & Normal \\
$\mathrm{A}_{1} \mathrm{~B}_{2}$ & 15 & .153 & .22 & Normal \\
$\mathrm{A}_{2} \mathrm{~B}_{1}$ & 15 & 0.094 & .22 & Normal \\
$\mathrm{A}_{2} \mathrm{~B}_{2}$ & 15 & .153 & .22 & Normal
\end{tabular}

Homogeneity test using the Barlet test is carried out on: a. Homogeneity tests the test data on the learning outcomes of two treatment groups with the learning motivation categories of high motivation and low motivation categories, namely between groups given the Numbered Head Together (NHT) learning model with conventional learning groups as well as high motivation and low motivation learning groups (A1, A2, B1, B2), b. Homogeneity testing of the four cells in the study design was cell groups A1B1, A1B2, A2B1, A2B2.

Testing the homogeneity of variance through the $\chi^{2}$ approach with the test criteria accepting Ho if count 2 count $<\chi 2$ tables, which means homogeneous variance and reject Ho if $\chi^{2}$ count $\geq \square$ tables 2 tables. Tested at the level of confidence $\alpha=0.05$; $\mathrm{dk}=\mathrm{K}-1$.

Significant test results and tests for the variants of each data group can be summarized in table 2 and table 3 below:

Table 2. Summary of Test Results of the Fourth Homogeneity Variance of the Research Design Group

\begin{tabular}{|c|c|c|c|c|c|c|}
\hline Group & $\begin{array}{l}\text { Separate } \\
\text { Variance }\end{array}$ & $\begin{array}{c}\text { Combined } \\
\text { Variant }\end{array}$ & $\begin{array}{c}\text { Price } \\
\text { B }\end{array}$ & $\begin{array}{c}X^{2} \\
h\end{array}$ & $\begin{array}{c}X^{2} t(0.95) \\
(3)\end{array}$ & $\begin{array}{c}\text { Informati } \\
\text { on }\end{array}$ \\
\hline $\mathrm{A}_{1}$ & 136.1 & \multirow{4}{*}{178.20} & \multirow{4}{*}{$\begin{array}{c}261.1 \\
0\end{array}$} & \multirow{4}{*}{3.55} & \multirow{4}{*}{7.82} & \multirow{4}{*}{$\begin{array}{l}\text { Homogen } \\
\text { eous }\end{array}$} \\
\hline $\mathrm{A}_{2}$ & 200.0 & & & & & \\
\hline $\mathrm{B}_{1}$ & 240.3 & & & & & \\
\hline $\mathrm{B}_{2}$ & 136.4 & & & & & \\
\hline
\end{tabular}

Table 3 . Summary of Test Results for the Variance of Homogeneity in the Fourth Research Design Group 
http://ijeds.ppj.unp.ac.id/index.php/IJEDS

\begin{tabular}{|c|c|c|c|c|c|c|}
\hline $\begin{array}{c}\text { Exo } \\
\text { uncle } \\
\text { Pok } \\
\end{array}$ & $\begin{array}{l}\text { Separate } \\
\text { Variance }\end{array}$ & $\begin{array}{c}\text { Combined } \\
\text { Variant }\end{array}$ & $\begin{array}{c}\text { Price } \\
\text { a B } \\
\end{array}$ & $X^{2} h$ & $\begin{array}{c}X^{2} t(0.95) \\
(3)\end{array}$ & Information \\
\hline $\mathrm{A}_{1} \mathrm{~B}_{1}$ & 33.5 & \multirow{4}{*}{107.79} & \multirow{4}{*}{112.00} & \multirow{4}{*}{3.89} & \multirow{4}{*}{7.82} & \multirow{4}{*}{ Homogeneous } \\
\hline $\mathrm{A}_{1} \mathrm{~B}_{2}$ & 108.5 & & & & & \\
\hline $\mathrm{A}_{2} \mathrm{~B}_{1}$ & 138.3 & & & & & \\
\hline $\mathrm{A}_{2} \mathrm{~B}_{2}$ & 151.0 & & & & & \\
\hline
\end{tabular}

From the results of the above table it can be seen that the value of $\chi^{2}$ from the two data groups is smaller than $\chi^{2}$ table at the level of confidence $\alpha=0.05$. This means that all data groups tested have homogeneous variants.

The results of normality and homogeneity test data show that the data groups in this population come from populations that are normally distributed and have homogeneous variants. Thus, the normality and homogeneity of data requirements are met so that it can be continued with Analysis of Variance (ANAVA) in testing the research hypothesis. The results of hypothesis testing can be summarized in table 4 below:

Table 4. Summary of Two-Anova Results for Social Studies Learning Data

\begin{tabular}{|c|c|c|c|c|c|c|}
\hline \multirow{2}{*}{ Source of Variance } & \multirow[t]{2}{*}{ JK } & \multirow[t]{2}{*}{$\mathbf{d b}$} & \multirow[t]{2}{*}{ RJK } & \multirow[t]{2}{*}{$\mathbf{F}_{\text {coum }}$} & $\mathbf{F}_{\text {tate }}$ & \multirow[t]{2}{*}{ Ket } \\
\hline & & & & & $\mathrm{a}=0.05$ & \\
\hline Learning Model (A) & 135.00 & 1 & 135.00 & 1.93 & 1.84 & Sig \\
\hline Motivation (B) & 1983,75 & 1 & 1983,75 & 28.32 & 1.84 & Sig \\
\hline Inter $\mathrm{AB}$ & 2600.42 & 1 & 2600.42 & 37,13 & 1.84 & Sig \\
\hline Inner Error & 3922.08 & 56 & 70.04 & - & - & \\
\hline Total & 8641.25 & 59 & & - & & \\
\hline
\end{tabular}

Interaction and significance of the main influence between the learning model and learning motivation in the analysis of variance above, the test is continued by using the Turkay test between pairs of data to determine which group average is higher between the two data sets paired.

Table 5. ANAVA Results for the Next Stage with the Tukey Test

\begin{tabular}{|c|c|c|c|}
\hline Comparison Group & $\mathbf{Q H}$ & $\begin{array}{c}\mathbf{Q t}(= \\
\mathbf{0 . 0 5})\end{array}$ & Information \\
\hline $\mathrm{A}_{1} \mathrm{~B}_{1}$ and $\mathrm{A}_{2} \mathrm{~B}_{1}$ & 11.42 & 2,4 & Significant \\
\hline $\mathrm{A}_{1} \mathrm{~B}_{2}$ and $\mathrm{A}_{2} \mathrm{~B}_{2}$ & 3.16 & 2,4 & Significant \\
\hline
\end{tabular}




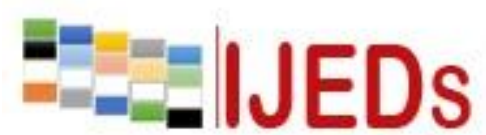

http://ijeds.ppj.unp.ac.id/index.php/IJEDS

International Journal of Educational Dynamics

Vol. 2 No. 1 (pp. 55-61) Desember 2019

p_ISSN 2655-4852

e ISSN 2655-5093

\section{CONCLUSION}

Based on the research findings and discussion of the results of the study, it can be concluded as follows: 1. Overall learning outcomes of social studies students who are treated with Cooperative learning type Numbered Head Together (NHT) are higher than the results of social studies learning students who learn a re given conventional learning. 2. For students with high category learning motivation, social studies learning outcomes with the type of cooperative learning if Numbered Head Together (NHT) are higher than students who are being given conventional learning. 3. For students with low learning motivation, social studies learning outcomes with the type of cooperative learning Numbered Head Together (NHT) are lower than students who are being given conventional learning. 4. There is an interaction effect between cooperative learning with the Numbered Head Together (NHT) type and conventional learning with learning motivation (high and lace categories ) on social studies learning outcomes.

\section{REFERENCES}

Ministry of National Education. 2003. RI Law No. 20 of 2013 concerning the National Education System.

Haraha p, Juniati. 2016. The Effect of the Numbered Heads Together (Nht) Method and Audiovisual Media on Learning Outcomes of Islamic Education in 12 High School Students in Medan . E-Thesis. Medan: Postgraduate of North Sumatra State Islamic University

Isjoni. (2010). Cooperative Learning Improves Communication Intelligence Between Students . Yogyakarta: Student Library.

Ibrahim, M uslimin. 2000. Cooperative Learning. Surabaya: University Press.

Lie, Anita. (2007). Cooperative Learning, Practicing Cooperative Learning in Classrooms . Jakarta: Grasindo.

Slameto 2003. Educational Evaluation. Ofsel Graphic Light. 